Fecha de recepción: julio 2020

Fecha de aprobación: octubre 2020

Fecha publicación: enero 2021

\section{Publishing Children Books by Minority Voices in Canada: The Case of Groundwood Books}

Silvana N. Fernández ${ }^{(1)}$

\begin{abstract}
In Canada today the children's book publishing scene is quite different from what it used to be in the 1970s and 1980s. Even if most publishers are small and rely heavily on federal grants the sheer range of publishing houses which feature the multicultural composition of the country for children and young adult readers is vast. The pendulum covers houses such as Annick Press, Fifth house, Second Story, or Theytus Books. The situation forty years ago though was radically different. In those days one of the groundbreaking houses was Groundwood Books. In this article we intend to look into the origins of the project, the wider political, social and cultural context, and three works by minority voices which clearly marked the publishing house's profile and aspirations (Paul Yee's Tales from Gold Mountain, Thomas King's controversial A Coyote Columbus Story and Shirley Sterling's My Name is Seepeetza). Our aim thus is to afford insight into the part played by Groundwood Books in fostering a new poetics in children's books within the framework of Canada's nation-building process.
\end{abstract}

Keywords: Publishing- Children- Canada- Minority voices- Groundwood Books

[Abstracts in spanish and portuguese on the pages 255-256]

(1) Doctora en Letras por la Universidad Nacional de La Plata y Licenciada en Literatura Inglesa por la misma universidad. Se desempeña como Prof. Titular de Literatura Inglesa Medieval y Renacentista y Prof. Adjunta de Cultura y Civilización Inglesas. Ha realizado estancias de investigación en la Universidad de Toronto (Canadá) y es co-directora de un proyecto de investigación en IdIHCS - UNLP. Sus áreas de estudio son la literatura canadiense escrita por escritores guionados y la representación del espacio en William Shakespeare y Joseph Conrad. sfernandez@fahce.unlp.edu.ar

Nowhere is the question of cultural diversity more relevant than in Canada, a country forged by Native peoples, ${ }^{1}$ Inuit, Metis, European settlers and waves of immigrants from all over the world. When it comes to considering how this mosaic ${ }^{2}$ features in children and young adults books and the publishing world, Canadian book publishers for children and teenagers acknowledge that even if there is still work to be done to produce books that 
reflect current racial and cultural realities, their long history of working toward diversity is not to be downplayed. Many of today's publishing houses started with a mandate to reflect the multicultural and multi-ethnic makeup of a modern progressive Canada and among the many Canadian children and young adult's presses which haven taken strides in publishing diverse authors are houses such as Annick Press, Fifth House, Second Story, Theytus Books, Viking, or Inhabit Media.

The beginning of an indigenous literature in Canada came about in the nineteenth century in the form of catechism and alphabets published in Montreal, Quebec City or Halifax, locations of the first printing presses in Canada (Watson, 2001, p. 587); yet, the first works for children by Canadian writers were commonly published in New York, Boston or London. Furthermore, these publications written from the metropolitan centres aimed at middle-class domestic readers and displayed a fascination with the exotic and unfamiliar. As Gail Edwards holds in Picturing Canada: A History of Canadian Children's Illustrated Books and Publishing:

For young readers, the idea of 'Canada' was shaped by narratives that emphasized geographic and cultural otherness- a place of ice and snow, dark and dangerous wooded forests, infinite prairie expanses, and towering mountains, populated by mysterious, savage, and primitive peoples and dangerous animals (Edwards, 2010, p. 17).

Even if in 1912 under the guidance of Lillian Smith the Toronto Public Library saw the establishment of a highly acclaimed library service for children, between 1921 and 1950 the average range of children's titles published annually was of about ten (Watson, 2001, p. 587). The domestic market for Canadian authors and publishers was thus weak and this, together with the extent of sales of foreign titles, were worrying facts in the rising Canadian nationalism of the late 1960 s and early 70 s and the unrelentingly growing awareness of a multicultural society.

The fact that multiculturalism is formally acknowledged and incorporated in Canada's ${ }^{3}$ constitution reveals its significance for the nation's psyche. As Eva Mackey observes, its import to the creation of national identity and to the success of the nation- building project can be traced back to the 1960s when management and representation of that diversity revealed to be central to the realization of that project. The 1967 centennial celebrations were a high point in Canadian state-produced national sentiment. Among other things, a bicultural vision of the nation started to emerge and native people and "ethnic groups"4 acquired visibility in the celebrations (Mackey, 2002, p. 58). The 1970s, in turn, saw a growth and institutionalization of this project when the state attempted a clearer definition of the boundaries and hierarchies of difference in the Canadian nation.

From a historical perspective then the changes in the perception and status of ethnicity in Canada were slow until 1971. In that year multiculturalism became the official policy and there were substantial proclamations of responsibility concerning ethnic diversity. When Canada was recognized as multicultural by Prime Minister Pierre Trudeau, 'Multiculturalism within a Bilingual Framework' became not just the official state policy but also the sum and substance of Canadian identity. Following the 1969 Official Languages 
Act, which officially declared the country bilingual, the Canada's Multiculturalism Policy secured that two official languages coexisted but no official culture and no ethnic group would prevail. In this sense Canadian multiculturalism is decidedly entrenched in Canadian biculturalism. Yet, as Genetsch claims, the Ottawa-Quebec biculturalism, or Hugh Mac Lennan's 'two solitudes' which has marked the image Canada projected of itself, is but a myth and a simplification. Firstly, Canada's colonial history and the appropriation of land based on the concept of terra nullius, or an 'empty space', worked towards leaving out the Inuit and Native Indians, denying them the status of founding nations and disempowering them. Secondly, because of Canada's promotion of immigration, a large number of the population was neither of English or French descent nor belonged to the First Nations communities (Genetsch, 2007, pp. 1-2).

As a symbolic intervention, the policy of multiculturalism was then, according to Eva Mackey, an attempt to manage a potentially dangerous political situation through the recognition and management of culture. Multicultural policy extends the state recognition of multiple forms of difference so as to undercut Quebec's more threatening difference (Mackey, 2002, p. 64). Thus, the inauguration of multiculturalism was firstly aimed at defusing Quebec's claims of secession and secondly represented an attempt to redefine the symbolic system of Canada. Even if the implementation of the policy of multiculturalism aimed at sapping the strength of the secessionist claims of Quebec, the fact that a policy of assimilation was abandoned in favor of normative pluralism contributed to forging a national identity conceived as a mosaic, a Canadian national identity which inheres in the very difference of the nation's diverse cultures.

During periods of nationalist effervescence, namely after the introduction of Canadian citizenship, in the wake of the Canadian centennial, and upon the repatriation of the Canadian Constitution, there was a major development in publishing. According to Richter, the new availability of both national and provincial funding which explicitly supported publishing for children also exemplifies the strong political involvement in the creation of Canadian children's literature. Awards on the national, provincial and regional level have worked towards fostering Canadian publishing for children and, the creation of a national canon of Canadian children's literature (Richter, 2011, p. 294).

Many years after all these and other significant political, social and cultural developments started to take place in Canada, more specifically on November 9, 2013, some 250 guests gathered at the Toronto Public Library's Lillian H. Smith branch to celebrate the 35th anniversary of Groundwood Books, one of Canada's oldest children's book publishers. Groundwood founder Patsy Aldana ${ }^{5}$ was absent from the party since she was in China inaugurating an imprint for China Children's Press and Publications Group, the country's largest children's book publisher. In 1978, Aldana, at the time president of the Association of Canadian Publishers, borrowed $\$ 30,000$ from her mother and started Groundwood Books. She was then 32 years old. In 1979 Aldana became manager for Douglas \& McIntyre, ${ }^{6}$ the Vancouver-based publishing company which initially distributed Groundwood's books and then merged "in a complex relationship unique in Canadian publishing", which was crucial for the growth and expansion of the company (Edwards, 2010, p. 103). Douglas \& McIntyre, on the lookout for a Toronto outpost, purchased Groundwood's inventory while Aldana continued keeping control over the company and all copyrights. 
According to Aldana, the reason that drove her to found Groundwood was an awareness of a paucity of Canadian children's titles. Books such as Anne of Green Gables (1908) by Lucy Maud Montgomery, Alligator Pie (1974) by Dennis Lee and other similar titles had been successful in the market, but except for Tundra Books there were no publishers specializing in children's literature. "Because I worked at a children's bookstore and I was working at the Women's Press," she said, "I could see that there was a real hunger and need for Canadian children's books" (Williams, 2013). She had to put up a fight against the deeply entrenched notion that Canadian children's books were not valuable and, least of all, marketable. "I remember a conference in Vancouver, and all these people were going around saying Canadian books are terrible," she recounted. "That was before Groundwood actually started, and I remember thinking, 'Well, we'll show them.' According to her, that if a publisher puts out high-quality Canadian children's books, there would be a market, and she was right (Williams, 2013).

The early 1980s happened to be an exceptional time to publish Canadian children's books. Not only could children's bookstores be found in most major Canadian cities, but also, according to Aldana, it was 'the great heyday of Canadian school libraries. Every school felt they had to have a library, and the librarians were properly trained and they were interested in Canadian authors" (Williams, 2013).

When nearing the end of the decade questions related to authenticity of voice rose to prominence, Aldana said she realized there was a lack of diversity in Canadian children's literature. Unlike the U.S. publishing houses which were bringing out good quality books written by black authors featuring black children, in Canada there was scant writing by any minority authors. "That's where we found a niche that was different from other people, and it became a specialty for Groundwood," she remarked wile she cited Paul Yee's Tales from Gold Mountain, about the exploitation of Chinese immigrants, and Thomas King's controversial A Coyote Columbus Story, a folkloric take on 1492 told from the native North American perspective, as titles that helped build Groundwood's reputation (Williams, 2013).

In 2005 Aldana arranged for Scott Griffin, who had recently purchased House of Anansi Press, to acquire Groundwood Books from Douglas \& McIntyre (Medley, 2012) and in January 2013 Aldana officially stepped down from her role as publisher and Sheila Barry took over. When Barry died on November 15, 2017. Semareh Al-Hillal ${ }^{7}$ was named publisher of Groundwood in April.

Groundwood Books, which accounts for $40 \%$ to $50 \%$ of Anansi's revenue in any given year, is primarily an institutional publisher rather than a trade publisher. This means they predominantly sell to schools and libraries rather than through stores. (Medley 2012) Groundwood thus, even if not the first dedicated to children, ${ }^{8}$ has undoubtedly pioneered Canadian topics and multicultural themes such as the ones present in the books under consideration, namely Tales from Gold Mountain. Stories of the Chinese in the New World (1989), A Coyote Columbus Story (1992) and My name is Seepeetza (1992).

Paul Yee's Tales from Gold Mountain: Stories of the Chinese in the New World was first published in 1989 and was last reprinted in paper format in 2011 and in digital format in 2014. This picture-book illustrated by Simon Ng and edited by Michael Solomon was winner of the Sheila A. Egoff Children's Literature Prize, the IODE Violet Downey Book Award 
and the IODE National Chapter Award. The book contains a landmark collection of eight stories which describe the extraordinary circumstances of the Chinese who came to build the railroad in Canada and the United States. The stylised full-page illustrations by Simon $\mathrm{Ng}$ both highlight the poignancy of the narratives and reveals the character nuances of the protagonists. In this book historian and archivist Yee artfully blends historical fact and folklore motifs and conveys the sorrows and hopes of Chinese immigrants coming to Canada in the $19^{\text {th }}$ century to search for gold, build the transcontinental railway, and engage in all kinds of menial jobs.

Yee, who considers himself to be third-generation Canadian, though actually he is the first one in his family to be born in Canada, thus writes from an inside perspective about what it means to be a member of a visible community in Canada. These stories, by offering Chinese-Canadians knowledge about their history, reveal an awareness of the importance of shared history and culture for identity formation. The popular historical phrase Gumshan or "Gold Mountain", a key signifier in the Chinese North American imagination, is strategically used in the title and is also structured in the framework of the book. The opening story, "Spirits of the Railway", and the closing one, "The Revenge of the Iron Chink", feature the historical presence of the Chinese immigrants in pioneer projects of the Canadian Pacific Railway and the British Columbia salmon industry. Both stories contextualise the physical hardships which the traditional legendary heroes in myth have to face, one in the building of the railway and the other in the frontier industry which exploited salmon. As to the social milieu, both stories depict the racial discrimination and dehumanizing social environment the labourers have to face. In "The Friends of Kwan Ming" portrays the fates of Chinese immigrants in a job market which offered them positions ony in the service industry whereas in "Gambler's Eyes" Yee engages with the prejudice and discrimination which a man of mixed descent has to live through both in Chinatown and among the Caucasian population. In "Ginger for the Heart", "Sons and Daughters" and "Forbidden fruit" Yee takes issue with the subordination of women in a male-oriented social order and in "Rider Chan and the Night River" the author fleshes out a minority hero who, working as a courier on the frontiers in the days of the Gold Rush, keeps watch over the moral order of Gold Mountain.

These folktales have a three-fold nature, creating mythology as a foundation, securing Chinese-Canadians recognition ${ }^{9}$ by other cultural groups in Canada and affording them a better understanding of Canada's largest racial minority (Richter, 2011, p. 276). Yee's stories are thus part of a collective voice ${ }^{8}$ which not only brings out a an experience and a heritage largely unrecorded, excluded or misrepresented by the media but also serves to redress this historical injustice, to deal with issues of Chinese Canadian history and to confront racism past and present (Chao, 1997, p. X). Furthermore, Yee's craftmanship as a storyteller together with the power of Ng's illustrations attest to the power of legend and myth to reach out to an audience which includes more than children and encompasses "anybody who wanted to read stories" (Yee, 1990, p. 346).

A Coyote Columbus Story by Thomas King, ${ }^{10}$ first released by Groundwood in 1992. was inspired by the quincentennial of the Columbus' voyage in 1492. King had tried for many years to find a publisher for his book in the USA and eventually he found one in Canada, in Groundwood Books, by then an imprint of Douglas \& McIntyre. The book which is 
aimed at 5-8 old readers, was short-listed for the Governor General's Literary Awards in 1992, and has gone through many printings, the last being in 2007.

Thomas King, author of Cherokee-Greek descent, has written both adult and children's books ${ }^{11}$ addressing the Aboriginal question. Unlike adult fiction, picture books for children do not show the same unblinking view of oppression, abuse, poverty, poor health; rather, as Wolf and DePasquale hold, the one striking difference between them lies in tone (Wolf \& DePasquale, 2008, p. 91) and locating these darkness and anger topoi becomes a problem of reading and not of content. They are undoubtedly there, though crucially meshed with "a sense of cultural affirmation, renewal and hope" which cannot be untangled from pressures, on the one hand, to produce images which counteract stereotypical views of "the drunken, lazy, or promiscuous Indian" and, on the other, to meet the general expectations of age appropriateness related to children's literature (Wolf \& DePasquale, 2008, p. 91).

In A Coyote Columbus Story, Thomas King chose to tell a new kind of Columbus story, a retelling from a Native point of view in which Coyote, ${ }^{12}$ the trickster, creates the world and all the creatures in it. She is in full control of events until a funny-looking red-haired man named Columbus disrupts her plans. Unimpressed by the wealth of moose, turtles and beavers in Coyote's land, columbus instead is interested in the human beings he can take to sell in Spain.

Thomas King deploys a good number of literary devices and tricks to challenge the stereotypes surrounding the Voyages of Discovery. In doing so, he naughtily beckons children to laugh with him at the crazed pranks of Coyote, who inadvertently and haphazardly allows Columbus to cause the ruin of his human friends. More importantly, in his creation, King makes the point that history is not neutral and is, undoubtedly, influenced by the culture of the reporter. The originality of the book lies not only in the pungent storyline but also in William Kent Monkman's psychodelic illustrations that bring everything fully to life.

My Name is Seepeetza, by Salish writer Shirley Sterling, ${ }^{13}$ was published by Groundwood on November 1st, 1992 and since that time the book has gone into its thirteenth reprint, the last being in 2008. The book, aimed at students in grades $4-7$ but often read by adults, has been acclaimed in both Canada and the United States. In Canada it was short-listed for a Governor General's Award in 1993 and won the Sheila A. Egoff Children's Literature Prize and the Laura Steiman Award for Children's Literature.

The reading frame for My Name is Seepeetza is the sad fate of approximately 150,000 First Nations, Métis, and Inuit children who were, for over a century, removed from their homes and sent to live in residential schools ${ }^{14}$ across Canada. The schools were created and funded by the federal government in the belief that Indigenous peoples were uncivilized and needed to be 'saved' from themselves. In reality, that 'education' cost Indigenous children the loss of their families and communities, their indigenous languages, and their traditions. Sterling, in the voice of a 10-year-old girl who keeps a secret journal in a fictional place called Kalamak, in British Columbia, recounts her experiences in the Kamloops Indian Residential School ${ }^{15}$ in the late 1950s. At a time when First Nations children were forcibly taken from their parents under threat of prison, forbidden to speak their language and often suffered all forms of abuse and neglect, Seepeetza offers readers an insight into the loneliness she experiences with a frank and candid approach for young readers. Her 
daily entries, from September 1958 to August 1959, relate the mundane and the horrific, from coping with schoolyard bullies to the death of a young boy by hanging. What shines through is the indomitable spirit of childhood.

Now on reading lists from Grade 4 classrooms to universities throughout North America, My Name is Seepeetza has been hailed for its power to bring memory forward and to acknowledge a trauma which is part of Canadian history.

According to Royson James (Grimaldi, 2014), the purpose of encouraging children to read is not simply to promote literacy. Literature has powerful qualities beyond didactic practicality. The aim is to introduce literature that a child can invest in-that will provide both intellectual stimulation and emotional reinforcement. Books that raise questions of culture, familial identity, and social surroundings are crucial to this process. To ignite a love of literature, one must encourage literature with which students can identify: one that speaks to their fears, their interests, their needs.

Groundwood Books' mission as spelt out on its website is "to publish books dedicated to the production of children's books of the highest possible quality for all ages, including fiction, picture books and nonfiction." Their primary focus is "on works by Canadians" although they "sometimes also publish outstanding books from other countries". These books "tell the stories of people whose voices are not always heard. Books by the First Peoples of this hemisphere have always been a special interest, as have those of others who through circumstance have been marginalized and whose contribution to our society is not always visible" (House of Anasi).

The books surveyed in this article, namely Paul Yee's Tales from Gold Mountain, Thomas King's A Coyote Columbus Story and Shirley Sterling's My Name is Seepeetza intervene thus in the sphere of "institutionalized multiculturalism", activating other elements which, on the one hand, inscribe ethnicity as a differential sign and which, on the other, do not bracket off the history of the ethnic subject. Authors and illustrators from non-dominant ethno-cultural groups work towards giving voice to the subaltern and articulating the tensions of marginalized and minority groups by speaking from the in-between of institutionalised multiculturalism.

In coming to address issues concerning Native peoples and the constitution of a hyphenated identity within the ongoing process of Canada's nation-building, Groundwood Books' publishing practice situates ethnic difference and the diasporic condition within a field of both contestation and hope arising from the interaction of Old and New Canadians; more importantly, Groundwood crafts and enacts a new and much needed poetics in children's books.

\section{Notes}

1. See LaRocque, Emma (2010). "Introduction". When the Other is Me: Native Resistance Discourse 1850-1990. Manitoba: University of Manitoba Press, 3-16.

2. Unlike the United States of America where understanding of national identity was conveyed in terms of the melting pot, in Canada the metaphor to symbolize the national 
character became the mosaic (Genetsch, 2007, p. 2). This ideal of the cultural mosaic is transformed by social class differences into what John Porter (1965) in The Vertical Mosaic: An Analysis of Social Class and Power in Canada (Toronto: University of Toronto) calls the vertical mosaic. Likewise, Eva Mackey (2002) in The House of Difference. Cultural Politics and National Identity in Canada problematises this notion of the cultural mosaic when addressing the tensions and intersections between, on the one hand, pluralism as an ideology and mythology and, on the other, the construction of a dominant national identity and culture in Canada:

In the Canadian 'mosaic', it is said, all the hyphenated cultures-French-Canadian, Native-Canadian, and 'multicultural-Canadian' - are celebrated. One problem with this formulation, as many have pointed out, is that multiculturalism implicitly constructs the idea of a core English-Canadian culture, and that other cultures become 'multicultural' in relation to that unmarked, yet dominant, Anglo-Canadian core culture [...]. (2002, p. 15) 3. Canada is the only country in the world to have formally included multiculturalism in its constitution.

4. Genetsch states:

"Whereas membership to an essentialist category such as race consigned one to a particular group, ethnicity stresses that belonging to a collective relies on affiliation, or the will to belong. Furthermore, because it is 'relative to time and place' ${ }^{15}$ ethnicity is also a category of difference more flexible than race in that it allows for a dynamics" (Genetsch, 2007, p. 13). 5. Patricia Aldana is currently the President of the IBBY Foundation. She was born and brought up in Guatemala and moved to Canada in 1971. In 1978 she founded Groundwood Books with a mandate to publish high-quality Canadian and international children's books for all ages; she remained the publisher until 2012. She was honoured with the Order of Canada in 2010 and has won prizes in Canada for her work in advocating the freedom to read for children and adults. She was elected to the IBBY Executive Committee in 1996 and served for four years. She was later re-elected in 2004 and served for two years as Vice-President before she was elected IBBY President in 2006 serving for four years until 2010. In 2013 The Writers' Union of Canada (TWUC) recognized the courageous work of Aldana, with its Freedom to Read Award and in 2014 she was elected President of the IBBY Hans Christian Andersen Award Jury and served for the 2016 and 2018 Awards. 6. D\&M is one of Canada's most eminent independent publishers with books that have won many national and international awards, including the Scotiabank Giller Prize and the Governor General's Literary Award. The company, originally called J.J. Douglas Ltd. and co-founded by Jim Douglas and Scott McIntyre, was established in 1970 and published its first title in the fall of 1971. A new chapter in British Columbian publishing began in 2013, when the Douglas \& McIntyre imprint was acquired by Howard and Mary White, owners of Harbour Publishing, who reorganized it as Douglas and McIntyre (2013) Ltd. (https:// books.bc.ca/dm-publishers/)

7. Semareh Al-Hillal was at Kids Can Books for 18 years as Associate Publisher before taking over at Groundwood Books.

8. Kids Can Press was founded in 1973; Annick Press was established in 1975; OWL Magazine, which led to Owlkids Books, printed its first issue in 1976; Orca Book Publishers, in Victoria, British Columbia, released its first book in 1982; Red Deer Press, which had 
begun life as a small poetry publisher in the mid-'70s, shifted focus to children's books in 1985. (https://books.bc.ca/dm-publishers/)

9. In the 1970 s community activists started to break through the wall of alienation and isolation. In 1979 as part of a political campaign to challenge Canadian discrimination in Canadian society a literary event which was called Writers' Workshop was jointly organized by some native-born Chinese and Japanese Canadians in Vancouver. This resulted in the publication of an inaugural text, Inalienable Rice: A Chinese \& Japanese Anthology (1979).

10. Thomas King is the award-winning author of The Inconvenient Indian, Medicine River, and Green Grass, Running Water. In 2014 his novel The Back of the Turtle won the Governor General's Award for English-language fiction.

11. Other Aboriginal writers who have written for both children and adults are Beatrice Culleton Mosionier, Jeannette Armstrong, Lee Maracle, Jordan Wheeler, Richard Van Camp, and Tomson Highway.

12. Coyote also appears in three other books Thomas King wrote for children: Coyote Sings to the Moon (1998), Coyote's New Suit (2004) and A Coyote Solstice Tale (2009).

13. Shirley Sterling is a member of the Nlakapamux or Thompson First Nation of the Interior Salish.

14. Government-funded, church-run residential schools operated from the 1870s until the final closure of a school outside Regina in 1996.

Also see Truth and Reconciliation Commission of Canada. http://www.trc.ca/about-us.html 15. Shirley Sterling says about the process of writing the book:

"The book came into existence by way of a creative writing course in Children's Literature. People ask me what motivated me to write the book and I reply, 'Six university credits.'

One day the instructor asked us to write a journal entry from when we were nine years old. The only thing I could remember from that year was the day I got a parcel from home. I wrote that entry and handed it in. My instructor, Sue Alderson, told me to drop everything else I was working on and write more entries. I told her I couldn't remember any more. She said to try. She said the entry was a good read. That was the one thing that would touch my heart. From my own ostracized childhood I remembered what it meant to have a good read; sometimes everything.

I went home and sat at my computer and decided to write whatever came to mind, the way it came to mind, regardless of how stupid it sounded, regardless of what the subject matter was. The concept of the first draft was crucial in this process as was the technology afforded by the computer. I needed to be able to go back and change, delete, cut and paste, update and save. The computer allowed the story to grow from the middle. The entry about St. Joseph came next, then the antics of that big, ribald horse, Baldy...

By the end of April I finished fifty pages and got my six credits. In the spring semester I took a tutorial with Sue and completed another fifty pages. She suggested I send the manuscript to a publisher. I was reluctant to do so because I didn't think any publisher in Canada would take the manuscript and besides I didn't really want this particular work published. My daughter has a degree in English literature. I asked her what she thought. She told me my manuscript had a message the world needs to hear. I sent it off in June 1991. It was in the book stores by December 1992. 
I remember what it was like to open the box the publisher (Groundwood Press) sent me, and to see the first twelve books. Beautiful royal blue, and the little girls in Irish costumes, and the child's script, and two of my names, right there on the cover. 'Ohhh,' I said."

(Sterling, 1995)

\section{Bibliographical References}

Al-Hillal, S. (2018, September 14). "Canadian Publishing 2018: Remembering Sheila Barry at Groundwood Books”. PW.https://www.publishersweekly.com/pw/by-topic/international/ international-book-news/article/77997-canadian-publishing-2018-remembering-sheilabarry-at-groundwood-books.html

Chao, L. (1997). "Mythologizing the Collective History and Reclaiming "Chinamen": Tales from Gold Mountain" in Beyond Silence. Chinese Canadian Literature in English. Toronto: TSAR Publications, pp. 51-65.

Edwards, G. y Saltman, J. (2002). “Towards a History of Design in Canadian Children's Illustrated Books". In Canadian Children's Literature/ littérature canadienne pour la jeunesse . $\mathrm{N}^{\circ}$ 107. Fall 2002, pp. 10-41. https://webcache.googleusercontent.com/search?q=cache :2uNjoUExWbMJ:https://ccllcj.ca/index.php/ccllcj/article/download/3901/3463+\&cd= $15 \& \mathrm{hl}=\mathrm{es} \& \mathrm{ct}=\mathrm{clnk} \& \mathrm{gl}=$ ar\&client $=$ firefox-b-d

Edwards, G. y Saltman, J. (2010). Picturing Canada: A History of Canadian Children's Illustrated Books and Publishing. Toronto: Toronto University Press.

Genetsch, M. (2007). "Difference and Identity in Multicultural and Postcolonial Discourse". The Texture of Identity. The Fiction of MG Vassanji, Neil Bissoondath, and Rohinton Mistry. Toronto: TSAR Publications, pp.1-21.

Genetsch, M. (2007). "Introduction". The Texture of Identity. The Fiction of MG Vassanji, Neil Bissoondath, and Rohinton Mistry.Toronto: TSAR Publications, pp. i-xii.

Grimaldi, N. (2014, May 5). "Multicultural Diversity in Children's Literature". The Town Crier.http://towncrier.puritan-magazine.com/books/multicultural-diversity-inchildrens -literature//

House of Anansi Press. “About Us". https://houseofanansi.com/pages/about-us-1

King, T. ([1992] 2002). A Coyote Columbus Story. Monkman, W. K. (Illustrator). Toronto: Groundwood Books, Douglas \& McIntyre.

LaRocque, E. (2010). "Introduction". When the Other is Me: Native Resistance Discourse 1850-1990. Manitoba: University of Manitoba Press, pp. 3-16.

Lepage, F.; Edwards, G. and Saltman, J. (2007). “Children's Authors and their Markets”. Gerson, Carole and Michon, Jacques (Eds.) History of the Book in Canada, Vol. 3. pp. 145-152.

Mackey, E. (2002). The House of Difference. Cultural Politics and National Identity in Canada. Toronto: University of Toronto Press.

Medley, M. (2012, November 23). “A Publisher's Year: Passing the littlest torch”. National Post. https://nationalpost.com/afterword/a-publishers-year-passing-the-littlest-torch 
Mendoza, J. (2005). “Goodbye, Columbus: Take Two”. Seale, D. \& Slapin, B. (Eds.) A Broken Flute: The Native Experience in Books for Children, UK, USA: Alta Mira Press \& Oyate, pp. 196-200.

Open Book (2018, November 26). “Groundwood Books Celebrates 40 Years of Innovative Children's Publishing” http://open-book.ca/News/Groundwood-Books-Celebrates-40Years-of-Innovative-Children-s-Publishing

Richter, M.V. (2011). Creating the National Mosaic: Multiculturalism in Canadian Children's Literature from 1950 to 1994. Amsterdam, New York: Rodopi.

Saltman, J. “A Publisher's Legacy: The Children's Books of Douglas \& McIntyre” https:// muse.jhu.edu/article/516142

Sterling, S. ([1992] 2011). My Name is Seepeetza. Toronto: Groundwood Books \& House of Anansi Press.

Sterling, S. (1995, October). "Seepeetza Revisited: An Introduction to Six Voices". Centre for the Study of Curriculum \& Instruction. Vol. $3 \mathrm{~N}^{\circ} 1$. University of BritishColumbia. http://einsights.ogpr.educ.ubc.ca/archives/v03n01/sterling.html

The Association of Book Publishers of British Columbia. "Douglas \& McIntyre". https:// books.bc.ca/dm-publishers/

Watson, V. (2001). The Cambridge Guide to Children's Books in English. Cambridge: Cambridge University Press.

Williams, L. A. (2013, Nov. 21). "Groundwood Books: Celebrating 35 Years". PW. https://www.publishersweekly.com/pw/by-topic/childrens/childrens-industry-news/ article/60104-groundwood-books-celebrating-35-years.html//

Wolf, D. (2012). “All my Relations”: Thomas King's Coyote Tetralogy”'. Gruber, E. (Ed.) Thomas King: Works and Impact.New York: Camdem House.

Wolf, D. \& DePasquale, P. (2008). "Home and Native Land: A Study of Canadian Aboriginal Picture Books by Aboriginal Authors", Reimer, M (Ed.) Home Words. Discourses of Children's Literature in Canada. Canada: Wilfrid Laurier University Press, pp. 87-106.

Yee, P. (1989). Tales from Gold Mountain: Stories of the Chinese in the New World. Ng, S. (Illustrator). New York: Macmillan Publishing Company.

Yee, P. (1990). "Paul Yee. Interview by Geoff Hancock" Linda Hutcheon \& Marion Richmond (Eds.) Other Solitudes: Canadian Multicultural Fictions. Toronto: Oxford University Press, pp. 343-348.

Resumen: En la actualidad la publicación de libros para niños en Canadá es bastante distinta de la que imperaba en los años 70 y 80 . Si bien todavía de tamaño pequeño y dependientes de subsidios federales, el número de casas editoriales que publican literatura para niños y jóvenes centrada en temáticas multiculturales ha experimentado un crecimiento notable. El rango es amplio e incluye nombres tales como Annick Press, Fifth house, Second Story, y Theytus Books. La situación hace cuarenta años era, sin embargo, radicalmente diferente. En aquellos días una de las casas innovadoras era Groundwood Books. En este artículo pretendemos analizar los orígenes del proyecto editorial, el con- 
texto político, social y cultural del país, y tres obras de voces minoritarias que claramente marcaron el perfil y las aspiraciones de la editorial (Tales from Gold Mountain, de Paul Yee, A Coyote Columbus Story, de Thomas King y My Name is Seepeetza, de Shirley Sterling). Nuestro objetivo es entonces examinar el papel desempeñado por Groundwood Books en la promoción de una nueva poética en la literatura infantil y juvenil en el marco más amplio del proceso de construcción de la nación canadiense.

Palabras clave: Editoriales - Infantil - Canadá - Voces minoritarias - Groundwood Books.

Resumo: Hoje no Canadá a cena de publicação de livros infantis é bem diferente do que costumava ser nas décadas de 1970 e 1980. Mesmo que a maioria dos editores seja pequena e dependa fortemente de subsídios federais, a enorme variedade de editoras que ilustram a composição multicultural do país para crianças e jovens adultos é vasta. A gama abrange editores como Annick Press, Fifth house, Second Story, or Theytus Books. A situação, há quarenta anos, era radicalmente diferente. Naqueles dias uma das editoras inovadoras era Groundwood Books. Pretendemos examinar neste artigo as origens do projeto, o mais amplo contexto político, social e cultural, e três obras de vozes minoritárias que marcaram claramente o perfil e as aspirações da editora (Tales from Gold Mountain, de Paul Yee, A Coyote Columbus Story, de Thomas King e My Name is Seepeetza, de Shirley Sterling). Nosso objetivo, portanto, é examinar o papel desempenhado pela Groundwood Books na promoção de uma nova poética nos livros infantis dentro da estrutura do processo de construção do Canadá.

Palavras chave: Publicação - Literatura infantil - Canadá - Vozes minoritárias - Groundwood Books.

[Las traducciones de los abstracts fueron supervisadas por el autor de cada artículo] 